Int. J. Dev. Biol. 61: 585-590 (2017)

doi: $10.1387 / \mathrm{ijdb} .170114 \mathrm{ph}$

\title{
The dawn of amphioxus molecular biology - a personal perspective
}

\author{
PETER W.H. HOLLAND* \\ Department of Zoology, University of Oxford, UK
}

\begin{abstract}
The cloning and embryonic expression analysis of an amphioxus Hox gene in 1992 marked the start of molecular analysis of cephalochordate development. Other papers quickly followed, including a description of the amphioxus Hox gene cluster in 1994, fuelling a resurgence of interest in a long-forgotten animal. I describe the academic background, laboratory experiments and field work leading to the earliest publications in amphioxus molecular developmental biology and explain their scientific impact. The story of amphioxus biology in the 1990s involved collaboration, team work, opportunistic meetings, serendipity, incredulous journal editors, stingrays, airport departure lounges and popcorn.
\end{abstract}

KEY WORDS: Branchiostoma, Tampa Bay, genome duplication, homeobox, ParaHox

\section{Introduction}

In 1932, Conklin started a publication with an apology. He wrote "Some excuse, or at least some explanation, seems to be needed for the publication of another paper on such a well-worked subject as the embryology of amphioxus" (Conklin 1932). Since the $19^{\text {th }}$ century, amphioxus (Branchiostoma sp.) had been a popular animal for biological investigation, particularly for studies of embryonic and larval development, because it was expected to give insights into an important evolutionary transition: the origin of vertebrates. But amphioxus faded from popularity as a topic for study through the middle of the twentieth century, as emphasis was placed on deciphering general principles from tractable 'model systems'such as mouse, chick, Xenopus and Drosophila. There were, however, still papers published on anatomy and endocrinology of adult amphioxus. As the molecular era dawned in the late 1970s and early 1980s, amphioxus had been largely forgotten. In my experience, most developmental, molecular and cell biologists in the 1980s and early 1990s had never heard of the animal.

I first encountered amphioxus as an undergraduate student in Oxford. I do not recall being shown a live specimen, even though they were readily available from the Marine Biological Association in Plymouth, but in laboratory classes we examined rubbery-looking fixed specimens and histological sections. These probably included actual specimens studied by Goodrich, Lankester and other names from the past, but this practical introduction did not light a spark. However, I remember writing an undergraduate assignment on the origin of the vertebrates set by one of my tutors, the dinosaur expert David Norman, around 1982 or 1983. For this essay I became engrossed in old works on the subject, including Willey's 1894 book 'Amphioxus and the Ancestry of the Vertebrates' which was gathering dust in the departmental library (Willey 1894). But that was the sum of my exposure to the cephalochordates, until 1990 when I made a decision to search for amphioxus Hox genes.

At the time almost no genes or cDNAs had been cloned and sequenced from any cephalochordate species, apart from (to my knowledge) some partial ribosomal DNA sequences and an insulin/IGF-related gene (Field et al., 1988; Chan et al., 1990). There were no widely available genomic or cDNA libraries, no gene expression patterns, and the prospect of a complete amphioxus genome sequence (or indeed several) was inconceivable. As with all molecular biology outside a few model systems, it was virtually a blank slate. The start of the amphioxus molecular biology field primarily involves two research groups working in parallel and sharing information freely: mine in the UK, and that of Linda and Nick Holland at Scripp's Institute of Oceanography, San Diego.

\section{The first amphioxus Hox gene}

The three 'amphioxus Hollands' converged on amphioxus from different directions and the surname does not reflect orthology. In 1987, I finished my PhD on a mouse Hox gene with Brigid Hogan

Abbreviations used in this paper: BBSRC, Biotechnology and Biological Sciences Research Council; PCR, polymerase chain reaction; SERC, Science and Engineering Research Council.

\footnotetext{
*Address correspondence to: Peter W H Holland, Department of Zoology, University of Oxford, South Parks Road, Oxford OX1 3PS, UK.

E-mail: peter.holland@zoo.ox.ac.uk - web: https://zoo-pholland.zoo.ox.ac.uk (iD http://orcid.org/0000-0003-1533-9376
} 
(one gene - one PhD in those days) and I had become interested in trying to compare homeobox genes between taxa. It is difficult to convey the level of excitement, yet fog of confusion, that surrounded the homeobox gene field at the time. Looking back, we were only glimpsing fragments of the bigger picture. We did not know how many Hox gene clusters existed in human or mouse, how similar the clusters were, how they evolved, or how comparable they were between taxa. We had ideas about conservation of function from a few spatial expression patterns in vertebrate development, but there were also sceptical voices. We had no appreciation of the great diversity of homeobox genes. On being given the opportunity to start my own lab that same year, I gambled on trying to apply molecular methods to investigate chordate evolution and Hox genes were inevitably going to be amongst the genes I tried to examine.

With PCR fragments of a few amphioxus Hox genes as preliminary data, around 1990 I obtained a grant from SERC (a forerunner of BBSRC) with the aim of making genomic libraries from Branchiostoma lanceolatum, isolating longer Hox gene clones, and examining gene expression in embryos obtained by spawning animals collected in Plymouth. The plan was to use embryonic Hox gene expression boundaries as clues to homology of body regions between taxa, specifically to test whether the vertebrate brain (or part of it) was a novelty or whether it was homologous to the amphioxus cerebral vesicle, as Willey had discussed in 1894. Through a chance set of meetings, involving Thurston Lacalli and Andrew Lumsden, I heard that Nick and Linda Holland in San Diego (neither of whom I knew) were also planning to work on amphioxus Hox genes. Nick wrote to share the text of their grant application and to suggest collaboration; amazingly, our two proposals were almost identical although formulated completely independently. Linda and Nick's background to the project was quite different to mine, and crucially they had already worked out how to spawn reliably the Florida amphioxus, Branchiostoma floridae, using a population of animals in Tampa Bay, Florida (Holland and Holland 1989). Linda was an experienced molecular biologist, but had not yet started to clone amphioxus genes and had not worked on Hox gene expression. I like to think that we had the perfect basis for a collaboration: they knew the animal and I knew the genes.

I immediately shelved plans to work on $B$. lanceolatum and switched to $B$. floridae so that we had guaranteed access to embryos. Linda sent me some high quality genomic DNA and my research assistant, Nic Williams, made a genomic library. Using our $B$. lanceolatum PCR fragments as probes, we isolated phage clones for several Hox genes. The first clone we fully sequenced was a clear orthologue of the Hox3 paralogy group (AmphiHox3 as we called it). I tried radioactive in situ hybridisations to adult amphioxus and these gave strong signals in the neural tube, but we could not work out position in the body and in any case we really needed to look in embryos. So in the spring of 1992 Linda obtained a small travel grant from the American Philosophical Society and came over to Oxford with a box of fixed $B$. floridae embryos, house-sitting for some of my friends to save our limited funds. We had one goal. We needed to get whole mount in situ hybridisation working in amphioxus embryos. We battled against frustratingly high backgrounds and low signals, trying a range of protocols and peering hopefully at either uniformly purple or uniformly white embryos. But after several weeks Linda had success: our first dish of stained embryos showing Hox expression patterns and a sharp anterior boundary in the neural plate. Linda recalled the moment as follows: "Peter and I looked at each other. We said nothing. Our careers were both made that day" (Holland 2010). That may sound extreme, but it was certainly one of those rare moments of breakthrough in science.

Our article reporting expression pattern of the first amphioxus Hox gene, indeed the first ever gene expression pattern described in amphioxus, was submitted to Development. It described the gene sequence and expression pattern, and made a proposal that the vertebrate hindbrain was homologous to part of the amphioxus spinal cord, far behind the cerebral vesicle. The paper was received positively and made the front cover of the November issue (Holland et al., 1992). But while it was in press, I had another opportunity to show the homeobox community what we had been doing. Every few years, Walter Gehring organised a small and intimate meeting on homeobox genes in the Swiss village of Ascona, and in 1992 I had been accepted as an attendee: not a speaker, but a chance to give a poster. I stood excitedly by my display which included the gene sequence, some giant photos of stained embryos, and the usual outrageous speculations. Almost the first person to walk past was the outspoken Editor-in-Chief and founder of the prestigious journal Cell, Ben Lewin. I had never met him, but I had certainly heard of him and I owned his textbook. He paused for a second, didn't look at me, and exclaimed loudly to the room "What the **** is an amphioxus?"Next was a more positive encounter. Bill McGinnis, the person whose early papers on the homeobox I had found so exciting, stopped and chatted. He was both enthusiastic and encouraging. I learnt later that he had sequenced a partial clone of an amphioxus Hox gene himself in 1991, but hadn't pursued it further (for the record, he had AmphiHox7). Walter Gehring was equally excited, so much so that he squeezed an extra slot into the meeting so I could present a summary of the work, on the final night, as the final talk, just as the bar was in danger of closing.

\section{Tampa Bay: centre of amphioxology}

Tampa, Florida, proudly displaying 'All-America city 1990' signposts alongside strip malls of fast food restaurants, became the summer retreat for the amphioxus world. From the early 1990s onwards, for over 20 years, almost every researcher in the world interested in amphioxus genes or development had at one time or another come to Tampa to join the growing amphioxus community. The annual gathering, stretching through much of July and August, was an ever-changing mix of people who would work together each day, share resources and experience, and ultimately facilitate each other's research in a free and open way. The enterprise began in 1988, when Linda and Nick Holland worked out how to collect large numbers of amphioxus from the warm, shallow waters of Tampa Bay, and induce them to spawn using electrical stimulation (Holland and Holland 1989). After Linda and I got the first positive in situ results in early 1992, I started to come to Tampa in summer and did so for many years, carrying my own portable lab including microscope, centrifuge and chemicals. In the early years, our group was small: the ever-present faces being Nick, Linda, Dale Stokes and me. Dale was a graduate student working on amphioxus ecology and behaviour with Nick. He was endlessly energetic and entertaining (see Gorman 2004), and would constantly tease us about our molecular reductionism. Each year the numbers of people grew, with Nick and Linda and their students teaching everyone how to collect and spawn animals, and later how to microinject eggs. 


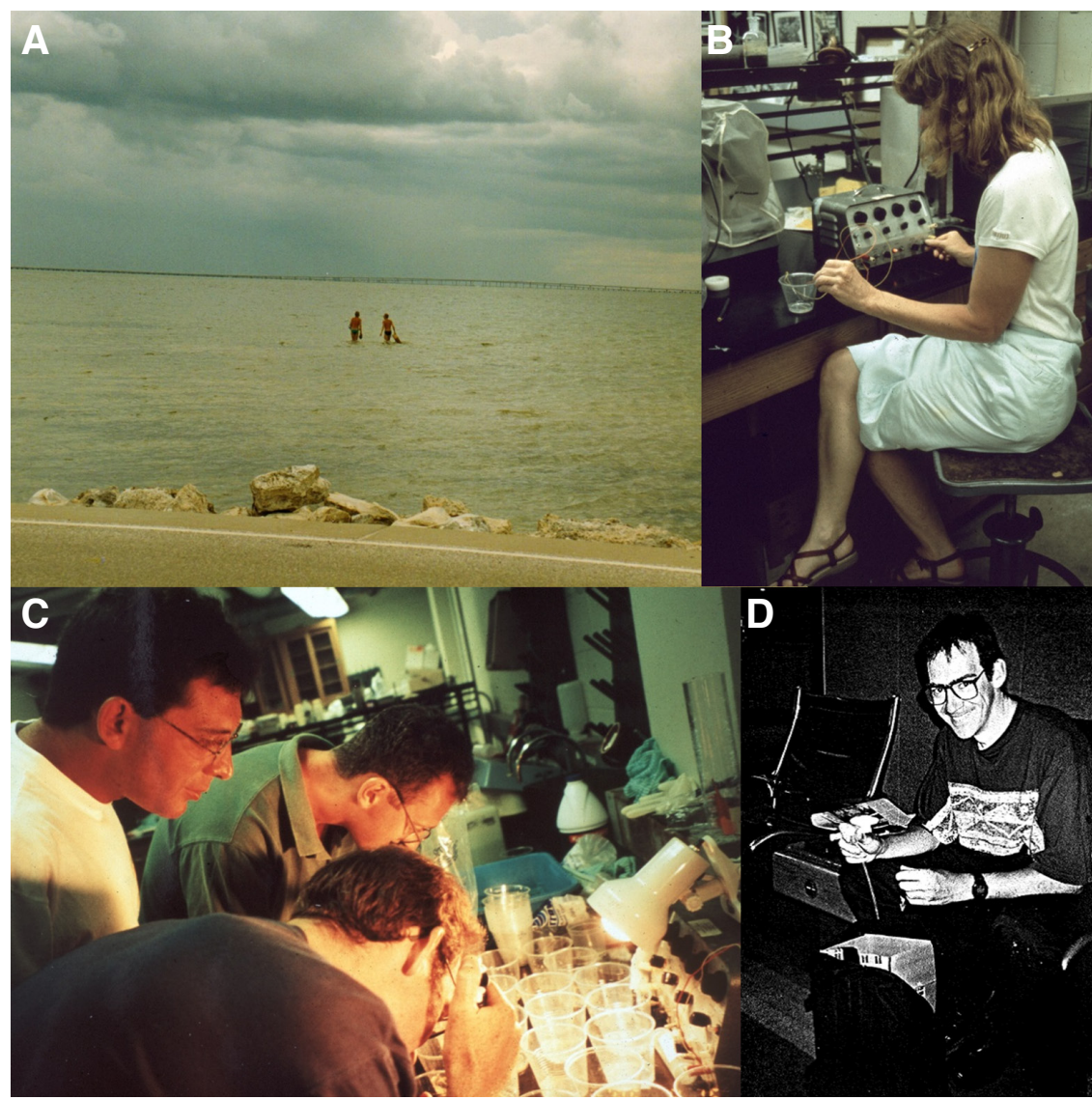

Fig. 1. Amphioxus developmental biology. (A) Researchers collecting B. floridae adults in Old Tampa Bay, Florida. (B) Linda Holland shocking animals to induce spawning. (C) Jordi Garcia-Fernàndez, Sebastian Shimeld and Peter Holland collecting eggs and sperm from spawning animals. (D) Sorting amphioxus embryos in Tampa International Airport.
Even when amphioxus failed to spawn, the work had its rewards for biologists because the waters teemed with animal life. Digging and sieving sand produced not just amphioxus but also enteropneusts (stinking of bromide), horseshoe crabs, molluscs and polychaetes, and it was common to watch spoonbills, ospreys and pods of dolphins in the distance. Stingrays were visible in the clear water, coming in to feed on amphioxus which they extracted by filtering the sediment (Stokes and Holland 1992), and a few unfortunate graduate students were stung by them. We always joked about bull sharks (Carcharhinus leucas) since the locals fished for them on the same beach, but the jokes turned to reality when Nick and Dale had to deter one using a shovel. Personally, my only close encounter with a suspected shark was a false alarm as the large shape swimming rapidly towards me tuned out to be an inquisitive manatee.

On the occasions that the amphioxus did spawn, a different routine set in. Eggs and sperm were collected and timed fertilisations set up (Fig. 1C). As embryos hatched from their vitelline membranes, the cultures were cleaned, and (if embryos were needed for in situ hybridisation, antibody staining or RNA extraction) timed samples taken for fixation. Since $B$. floridae embryos develop rapidly, reaching swimming neurulae in 13 hours, this meant regular time points had to be taken throughout the night and the following day, and possibly the next night as well. Sometimes it was possible to snatch a couple of hours sleep on the lab floor; more usually we would work through, fuelled by microwave popcorn and Ben \& Jerry's ice-cream. On one memorable occasion, the animals had been

The main problem we faced was that the animals could only be persuaded to release eggs or sperm on nights when they were going to spawn naturally in the field. And since the whole local population would reach this state synchronously, and the environmental triggers were unknown, we could not predict the nights on which induced spawning would be possible. The solution was to try every day. We had a routine worked out, which given perseverance guaranteed provision of thousands of staged embryos, although only every 6 to 10 days. Each day's field work started at around 3 pm, when armed with sieves and shovels the team would wade out into Old Tampa Bay to around waist deep, and dig and sieve sand for several hours (Fig. 1A). Digging and lifting sand from a metre of water in the Florida heat and humidity was back-breaking work. As the first of the evening thunder storms loomed, we would drive back to John Lawrence's laboratory at the University of South Florida, deposit the animals and meet for an early dinner at the ridiculously cheap Papa Loui's pizza restaurant. This is where experiments were planned, hypotheses discussed and ideas exchanged. At dusk, and back at the lab, male and female amphioxus would be carefully separated into plastic beakers and given pulsed non-lethal electric shocks (Fig. 1B). Most nights nothing happened. In this case, the animals would be returned to the sea the next day and the routine of digging, sieving, separating and shocking repeated again, and again, daily for a week or more. uncooperative for several weeks, and it was looking like I would return to the UK empty handed. However, with bags packed and a morning flight to catch, we had an enormous spawning with hundreds of animals producing eggs and sperm. The night was spent setting up fertilisations and fixing the earliest developmental stages, but the later stages presented a problem. The solution, which would not be possible today, was to fill my hand luggage with live embryo cultures, pipettes, and Falcon tubes, enabling me to preserve amphioxus embryos in the departure lounges of three airports (Fig. 1D).

\section{A flood of genes}

Each researcher who came to Tampa was pursuing their own research question, and many new collaborations were generated. My amphioxus research went in two initial directions: first, to clone additional genes that might give clues to homology of brains between amphioxus and vertebrates, and second, to attempt to clone all amphioxus Hox genes and characterise their genomic organisation. For the latter project, the arrival in my lab of Jordi Garcia-Fernàndez in 1993 was crucial, although I still question why he took on such a risky project. After all, we only had technology to make relatively short insert genomic libraries and we were unsure whether amphioxus Hox genes would be 
clustered at all. If they were, we did not know how many clusters existed or how large the intergenic distances would be. Library screening with PCR fragments and end-labelled oligonucleotides turned the lab into a whirlwind of bacteriophage cultures, Southern blots, DNA sequencing gels and impressive quantities of ${ }^{32} \mathrm{P}$. The work, however, was phenomenally successful and in just over a year Jordi had isolated and assembled more than 200 overlapping $B$. floridae genomic phage clones into a well-resolved and multiply confirmed genomic map containing 10 verified Hox genes linked into a single cluster (Garcia-Fernàndez and Holland 1994).

We were beginning to plan the paper when a confusing incident occurred. A publication from another group came out describing a set of short amphioxus PCR fragments, suggesting from sequence analysis (not linkage data) that amphioxus might have two Hox gene clusters (Pendleton et al., 1993). This flew in the face of our genomic mapping, and forced us into several months of additional experiments to discover why the two-cluster theory was in error. Eventually, our paper was sent to Nature and published in August 1994. Looking back, the impact of the early amphioxus gene cloning papers was massive. In a Nature News and Views article entitled 'Return of the amphioxus' Henry Gee wrote that it was "time to brush off the textbooks and welcome back an old friend"(Gee 1994). The cell and molecular biology community was now ready to embrace the animal, as judged by the large number of seminar and conference invitations we each received. I also received dozens of letters from researchers wishing to study their favourite genes in amphioxus, as of course did Linda and Nick Holland who were simultaneously publishing their own influential papers on B. floridae (for example, LZ Holland et al., 1996, ND Holland et al., 1996). Linda Holland and Jim Langeland also made excellent embryonic and larval cDNA libraries and these helped many researchers clone and study key genes, leading to advances in understanding the evolution of neural patterning, segmentation, mesoderm development and other developmental processes (for example, Langeland et al., 1998; Shimeld 1997, 1999; Kozmik et al., 1999).

One collaboration was particularly memorable since the resulting publication generated more questions about the acknowledgements than the science. Bernhard Herrmann asked if I wished to help clone the amphioxus homologue of Brachyury (or homologues as it turned out); this proved a successful collaboration, until I drafted the manuscript. At that point, Bernhard's graduate student refused to have his name on the paper, taking issue with the fact that I had interpreted the DNA sequence and expression data in terms of evolutionary descent. After much debate an uncomfortable compromise was reached, with the acknowledgements stating "We thank Hubert Ortner, Freiburg, for performing a major part of this work. Hubert Ortner was offered first authorship, but declined for reasons of conflict with his religious beliefs" (Holland et al., 1995).

\section{Genome duplications and genomic clusters}

In addition to raising the profile of amphioxus, and shedding light into body plan homology as we had planned, the early work started to have influence in additional directions. These included the demonstration of whole genome duplication in vertebrate ancestry and the presence of homeobox gene clusters other than Hox. In his now famous (but in its time controversial) 1970 book, Susumu Ohno proposed that vertebrates had undergone genome duplication in their evolutionary ancestry. Considering the data he had at the time (C-value and allozyme data), Ohno's work was way ahead of its time, but he was vague about proposed timing of genome duplications apart from suggesting that one was shared by amphioxus and vertebrates (Ohno 1970). I had read Ohno's book years earlier, but the details had not stayed with me and they were not foremost in our minds when studying amphioxus genes. A fortunate meeting, carefully choreographed by the brilliant but eccentric geneticist John Edwards, changed that completely. John was Professor of Genetics at Oxford and on hearing of our amphioxus work asked me to present at a small workshop he was organising on human and mouse gene mapping. He told me excitedly "Lundin is coming" although at the time I did not understand the significance of his comment. At the workshop Lars-Gustav Lundin presented a summary of his superb recent work proposing that much of the human genome could be arranged into four-fold paralogy groups (Lundin 1993). This was long before the human genome had been sequenced, but Lundin's work was already highly suggestive of two rounds of whole genome duplication sometime in human ancestry. However, Lars assumed timings based on Ohno's hypotheses, which I could see were not correct. I presented the amphioxus Hox cluster data, and our cloning of some other amphioxus genes, showing that amphioxus often had one copy where vertebrates had two, three or four. The two of us huddled in a corner excitedly discussing how our data fitted together: amphioxus was providing the first evidence that two whole genome duplications occurred just before the origin of vertebrates.

In our original description of the amphioxus Hox gene cluster, Jordi had found two 'posterior' genes, AmphiHox-9 and AmphiHox-10, but we suspected we had not reached the 'end' of the cluster (Garcia-Fernandez and Holland, 1994). Posterior Hox genes tend to be fast evolving and hard to isolate, and although we continued to hunt for these genes after the paper was accepted, we were struggling. The battle, however, turned up something quite unexpected. To put the discovery in perspective, it is key to realise that at the time it was thought that clustering of Hox genes was unique, and that all other homeobox genes were dispersed as single genes around the genome. One of the genomic phage clones that Jordi isolated in our genomic library screening turned out to span the $C d x$ gene. But this phage clone had a second restriction digest band that hybridized to a homeobox oligonucleotide probe. We confidently thought this signal probably came from an elusive posterior Hox gene, hopefully showing us that $C d x$ was linked to the 'end' of the Hox cluster as befits its posterior expression. It was not to be. Jordi had left the lab, and I pursued the cloning and sequencing. The key sequencing autoradiograph was developed on a Friday afternoon, 14 October 1994, and having no time to analyse it there and then, I rolled the X-ray film into my bag and headed home. To read the sequence, I taped the autoradiograph to a bedroom window that evening, scribbled down the series of A, C, G and T, and manually translated the sequence with the help of Lewin's textbook. I could see by eye that the sequence had the tell-tale homeodomain helices, but in the days before home internet there was nothing I could do to work out what homeobox gene the $C d x$-neighbour gene actually was. In the morning, I cycled to Blackwell's bookshop, plucked Denis Duboule's 'Guidebook to the Homeobox Genes' off the shelf, and sitting on the shop floor scanned each protein sequence in turn, in a sort of manual BLAST. It was clear: the amphioxus $C d x$-neighbour was the Xlox 
$(P d x)$ gene, indicating we had hit upon a separate clustering of homeobox genes. Two genes don't make a cluster (according to the manuscript reviewers); it took another four years, and the PhD work of Nina Brooke, to confirm this was a three gene cluster which we termed ParaHox (Brooke et al., 1998). Thus, work in amphioxus had revealed a second homeobox gene cluster, later found in humans and many other animals, and given new insights into the evolutionary history of homeobox genes.

\section{Conclusions and perspectives}

In this short article it has not been possible to mention all the early papers published on amphioxus molecular and developmental biology or to mention every person involved. Furthermore, I have given a personal and possibly incomplete account of the events of the 1990s. As the twentieth century ended, the amphioxus research field was moving ahead in two complementary directions: developmental and genomic. In the first area, there was considerable interest in establishing experimental manipulation protocols for amphioxus, thereby opening up the possibility of studying developmental mechanisms and testing how gene regulation or gene function evolved in chordates. In my lab, we wanted to study gene regulation and for this Hiroshi Wada, together with Miguel Manzanares in Robb Krumlauf's group, used reporter genes in transgenic mice as a testing ground for functional analysis of amphioxus Hox regulatory DNA (Manzanares et al., 2000). In California, Jr-Kai (Sky) Yu and Linda Holland were getting microinjection protocols working into unfertilized $B$. floridae eggs, enabling direct testing of enhancer function in amphioxus embryos (Yu et al., 2004). These early experiments have been built on by others, including similar microinjection methods for B. belcheri (Liu et al., 2013), a Tol2-mediated transgenesis method for $B$. lanceolatum developed by Kozmikova and Kozmik (2015), and successful gene deletion in B. floridae achieved by Guang Li and Yiquan Wang ( $\mathrm{Li}$ et al., 2014, 2017). Coupled with these technological steps forward, populations of Branchiostoma species have been found in several locations in China, Japan and Europe, and several laboratories around the world are now culturing amphioxus with spawning induced on demand by temperature shift. Hence, the amphioxus developmental biology community is no longer dependent upon natural spawning events in the field.

Turning to genomic biology, the amphioxus (and tunicate) molecular data gathered through the 1990s further strengthened the evidence for genome duplication in early vertebrate evolution, with amphioxus retaining the ancestral pre-duplication condition (Holland et al., 1994; Holland and Garcia-Fernàndez 1996; Sharman and Holland 1996; Furlong and Holland 2002). To compare large-scale genomic organisation between amphioxus and vertebrates, Filipe Castro developed methods for fluorescent in situ hybridisation to amphioxus chromosomes (Castro and Holland 2002, 2003; Castro et al., 2004), and in turn this amphioxus work assisted later attempts to understand diversity and genomic organisation of all homeobox genes across Metazoa (Holland et al., 2007; Butts et al., 2008; Tsai et al., 2013). The evidence for amphioxus diverging before the vertebrate genome duplication events gave an excellent platform from which to propose sequencing the complete $B$. floridae genome, and this was developed and pushed forward through the considerable efforts of Jeremy Gibson-Brown and Linda Holland. The Joint Genome Institute in California approved the project with sequencing led by Dan Rokhsar, and a complete draft was achieved by 2005. Two large genome papers, with 37 and 64 authors respectively, summarized the first analyses with the size and citation rates of these papers revealing the scale of the research community now interested in amphioxus (Putnam et al., 2008; Holland et al., 2008). Journal editors and funding agencies now know what an amphioxus is. Much more importantly, there is a renewed appreciation of the deep biological insights that can be gleaned from study of a diversity of animal taxa: in many ways, amphioxus was a trailblazer for the comparative approach. Comparative cell and developmental biology is no longer focussed solely on homologies between taxa, but offers the exciting prospect of uncovering the genetic and epigenetic basis of evolutionary change, adaptation and constraint across the animal kingdom.

\section{Acknowledgements}

I thank the many people who contributed to establishment of amphioxus as a tractable animal for study, especially Linda and Nick Holland. I am also indebted to the many students and colleagues who worked with me on the topics discussed, shared discoveries and frustrations, and exchanged bold ideas and wild speculations; I cannot name them all but Jordi GarciaFernàndez, Nic Williams, Hiroshi Wada, Seb Shimeld, Filipe Castro, Graham Luke and Nina Brooke deserve special mention. Thanks are also due to John Lawrence of the University of South Florida for allowing an annual invasion of assorted biologists to take over his lab, and the various funding agencies that showed the wisdom to support amphioxus research including the Science and Engineering Research Council (UK), Biotechnology and Biological Sciences Research Council (UK), Human Frontier Science Program, European Molecular Biology Organisation, Fundacao para a Cienica e a Tecnologia (Portugal), Uehara Memorial Foundation (Japan), the Leverhulme Trust, the Royal Society and the Japan Society for the Promotion of Science (JSPS). This article was written while the author held a JSPS Invitation Fellowship for Research in Japan.

\section{References}

BROOKE NM, GARCIA-FERNÀNDEZJ, HOLLAND PWH (1998). The ParaHox gene cluster is an evolutionary sister of the Hox gene cluster. Nature 392: 920-922.

BUTTS T, HOLLAND PWH, FERRIER DEK (2008). The Urbilaterian Super-Hox cluster. Trends Genet 24: 259-262.

CASTRO LFC, FURLONG RF, HOLLAND PWH (2004). An antecedent of the MHClinked genomic region in amphioxus. Immunogenetics 55: 782-784.

CASTRO LFC, HOLLAND PWH (2003). Chromosomal mapping of ANTP class homeobox genes in amphioxus: piecing together ancestral genomes. Evol Devel 5: 459-465.

CASTRO LFC, HOLLAND PWH (2002). Fluorescent in situ hybridization to amphioxus chromosomes. Zool Sci 19: 1349-1353.

CHAN SJ, CAO Q-P, STEINER DF (1990). Evolution of the insulin superfamily: cloning of a hybrid insuin/insulin-like growth factor cDNA from amphioxus. Proc Natl Acad Sci USA 87: 9319-9323.

CONKLIN EG (1932). The embryology of amphioxus. J Morph 54: 69-151.

DUBOULE D (1994). Guidebook to the Homeobox Genes. Oxford University Press, Oxford.

FIELD KG, OLSEN GJ, LANE DJ, GIOVANNONI SJ, GHISELIN MT, RAFF EC, PACE NR, RAFF RA (1988). Molecular phylogeny of the animal kingdom. Science 239: 748-752.

FURLONG RF, HOLLAND PWH (2002). Were vertebrates octoploid? Phil Trans Roy Soc $B$ 357: 531-544.

GARCIA-FERNÀNDEZ J, HOLLAND PWH (1994). Archetypal organization of the amphioxus Hox gene cluster. Nature 370: 563-566.

GORMAN D (2004). Dave Gorman's Googlewhack Adventure. Overlook Press, New York.

HOLLAND LZ (2010). BIO - Linda Z. Holland. Evo Dev 12: 109-112. 
HOLLAND LZ, KENE M, WILLIAMS NA, HOLLAND ND (1996). Sequence and embryonic expression of the amphioxus engrailed gene (AmphiEn): the metameric pattern of expression resembles that of its segment-polarity homolog in Drosophila. Development 124: 1723-1732.

HOLLAND LZ, ALBALATR, AZUMI K, BENITO-GUTIÉRREZÈ, BLOWMJ, BRONNERFRASER M, BRUNET F, BUTTS T, CANDIANI S, DE JONG PJ, DISHAW LJ, FERRIERDEK, GARCIA-FERNÀNDEZJ, GIBSON-BROWNJJ, GISSIC, GODZIK A, HALLBÖÖK F, HIROSE D, HOSOMICHI K, IKUTAT, INOKO H, KASAHARAM, KASAMATSU J, KAWASHIMA T, KIMURAA, KOBAYASHI M, KOZMIK Z, KUBOKAWA K, LAUDET V, LITMAN GW, MCHARDY AC, MEULEMANS D, NONAKA M, OLINSKI RP, OSOEGAWA K, PANCER Z, PENNACCHIO LA, PESTARINO M, RAST JP, RIGOUTSOS I, ROBINSON-RECHAVI M, ROCH G, SAIGA H, SASAKURA Y, SATAKE M, SATOU Y, SCHUBERT M, SHERWOOD N, SHIINA T, TAKATORI N, TELLO J, VOPALENSKY P, WADA S, XU A, YE Y, YOSHIDA K, YOSHIZAKI F, YU J-K, ZHANG Q, ZMASEK CM, PUTNAM NH, ROKHSAR DS, SATOHN, HOLLAND PWH (2008). The amphioxus genome illuminates vertebrate origins and cephalochordate biology. Genome Res 18: 1100-1111.

HOLLAND ND, PANGANIBAN G, HENYEY EL, HOLLAND LZ (1996). Sequence and developmental expression of AmphiDIl, an amphioxus Distal-less gene transcribed in ectoderm, epidermis and nervous system: insights into evolution of craniate forebrain and neural crest. Development 122: 2911-2920.

HOLLAND ND, HOLLAND LZ (1989). Fine structural study of the cortical reaction and formation of egg coats in a lancelet (= amphioxus), Branchiostoma floridae (phylum Chordata: subphylum Cephalochordata=Acrania). BiolBull176: 111-122.

HOLLAND PWH, GARCIA-FERNÀNDEZ J (1996). Hox genes and chordate evolution. Dev Biol 173: 382-395.

HOLLAND PWH, HOLLAND LZ, WILLIAMS NA, HOLLAND ND (1992). An amphioxus homeobox gene: sequence conservation, spatial expression during development and insights into vertebrate evolution. Development 116: 653-661.

HOLLAND PWH, GARCIA-FERNÀNDEZ J, WILLIAMS NA, SIDOW A (1994). Gene duplications and the origins of vertebrate development. Development 1994S: 125-133.

HOLLAND PWH, KOSCHORZB, HOLLAND LZ, HERRMANNBG (1995). Conservation of Brachyury $(T)$ genes in amphioxus and vertebrates: developmental and evolutionary implications. Development 121: 4283-4291.

HOLLAND PWH, BOOTH HAF, BRUFORDE (2007). Classification and nomenclature of all human homeobox genes. BMC Biology 5: 47.

KOZMIK Z, HOLLAND ND, KALOUSOVA A, PACES J, SCHUBERT M, HOLLAND LZ (1999). Characterization of an amphioxus paired box gene, AmphiPax2/5/8: developmental expression patterns in optic support cells, nephridium, thyroid-like structures and pharyngeal gill slits, but not in the midbrain-hindbrain boundary region. Development 126: 1295-1304.

KOZMIKOVA I, KOZMIK Z (2015). Gene regulation in amphioxus: an insight from transgenic studies in amphioxus and vertebrates. Mar Genomics 24: 159-166.

LANGELAND J, TOMSAJ, JACKMAN JR W, KIMMELCB (1998). An amphioxus snail gene: Expression in paraxial mesoderm and neural plate suggests a conserved role in patterning the chordate embryo. Dev Genes Evol 208: 569-577.

LI G, FENG J, LEI Y, WANG J, WANG H, SHANG L-K, LIU D-T, ZHAOH, ZHUY, WANG
Y-Q (2014). Mutagenesis at specific genomic loci of amphioxus Branchiostoma belcheri using TALEN method. J Genet Genom 41: 215-219.

LI G, LIU X, XING C, ZHANG H, SHIMELD SM, WANG Y (2017) Cerberus-NodalLefty-Pitx signaling cascade controls left-right asymmetry in amphioxus. Proc. Natl. Acad. Sci. USA 114: 3684-3689.

LIU X, LI G, FENG J, WANG X, WANG YQ (2013). An efficient microinjection method for unfertilized eggs of Asian amphioxus Branchiostoma belcheri. Dev Genes Evol. 223: 269-278.

LUNDIN L-G (1993). Evolution of the vertebrate genome as reflected in paralogous chromosomal regions in man and the house mouse. Genomics 16: 1-19.

MANZANARES M, WADA H, ITASAKA N, TRAINOR PA, KRUMLAUF R, HOLLAND $\mathrm{PWH}$ (2000). Conservation and elaboration of Hox gene regulation during evolution of the vertebrate head. Nature 408: 854-857.

OHNO S (1970). Evolution by Gene Duplication. Springer-Verlag, New York.

PENDLETON JW, NAGAI BK, MURTHA MT, RUDDLE FH (1993). Expansion of the Hox gene family and the evolution of chordates. Proc Natl Acad Sci USA 90: 6300-6304.

PUTNAM NH, BUTTST, FERRIERDEK, FURLONG RF, HELLSTENU, KAWASHIMA T, ROBINSON-RECHAVIM, SHOGUCHIE, TERRYA, YUJ-K, BENITO-GUTIÉRREZ E, DUBCHAK I, GARCIA-FERNÀNDEZ J, GRIGORIEV IV, HORTON AC, DE JONG PJ, JURKA J, KAPITONOV V, KOHARA Y, KUROKI Y, LINDQUIST E, LUCAS S, KAZUTOYO O, PENNACCHIO LA, SALAMOV AA, SATOU $Y$, SAUKA-SPENGLER T, SCHMUTZ J, SHIN-I T, TOYODA A, GIBSON-BROWN JJ, BRONNER-FRASER M, FUJIYAMA A, HOLLAND LZ, HOLLAND PWH, SATOH N, ROKHSAR DS (2008). The amphioxus genome and the evolution of the chordate karyotype. Nature 453: 1064-1072.

SHARMAN AC, HOLLAND PWH (1996). Conservation, duplication and divergence of developmental genes during chordate evolution. Neth J Zool 46: 47-67.

SHIMELD SM (1997). Characterisation of amphioxus HNF-3 genes: conserved expression in the notochord and floor plate. Dev. Biol 183: 74-85.

SHIMELD SM (1999). The evolution of the hedgehog gene family in chordates: insights from amphioxus hedgehog. Dev Genes Evol 209: 40-47.

STOKES MD, HOLLAND ND (1992). Southern stingray (Dasyatis americana) feeding on lancelets (Branchiostoma floridae). J Fish Biol 41: 1043-1044.

TSAI IJ, ZAROWIECKI M, HOLROYD N, GARCIARRUBIO A, SANCHEZ-FLORES A, BROOKS KL, TRACEY A, BOBES RJ, FRAGOSO G, SCIUTTO E, ASLETT

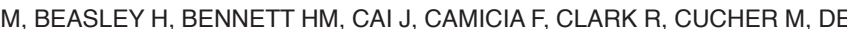
SILVAN, DAYTA, DEPLAZES P, ESTRADAK, FERNÁNDEZC, HOLLAND PWH, HOU J, HU S, HUCKVALE T, HUNG SS, KAMENETZKY L, KEANE JA, KISS F, KOZIOL U, LAMBERT O, LIU K, LUO X, LUO Y, MACCHIAROLI N, NICHOL $S$, PAPS J, PARKINSON J, POUCHKINA-STANTCHEVA N, RIDDIFORD N ROSENZVIT M, SALINAS G, WASMUTH JD, ZAMANIAN M, ZHENG Y, THE TAENIA SOLIUM GENOME CONSORTIUM, CAI X, SOBERÓN X, OLSON PD, LACLETTE JP, BREHM K, BERRIMAN M (2013). The genomes of four tapeworm species reveal adaptations to parasitism. Nature 496: 57-63.

WILLEYA(1894). Amphioxus and the Ancestry of the Vertebrates. Macmillan, London.

YU J-K, HOLLAND ND, HOLLAND LZ (2004). Tissue-specific expression of FoxD reporter constructs in amphioxus embryos. Dev Biol 274: 452-461. 


\section{Further Related Reading, published previously in the Int. J. Dev. Biol.}

From the American to the European amphioxus: towards experimental Evo-Devo at the origin of chordates

Jordi Garcia-Fernàndez, Senda Jiménez-Delgado, Juan Pascual-Anaya, Ignacio Maeso, Manuel Irimia, Carolina Minguillón, Ėlia BenitoGutiérrez, Josep Gardenyes, Stéphanie Bertrand and Salvatore D’Aniello

Int. J. Dev. Biol. (2009) 53: 1359-1366

https://doi.org/10.1387/ijdb.072436jg

Evolution of CUT class homeobox genes: insights from the genome of the amphioxus, Branchiostoma floridae Naohito Takatori and Hidetoshi Saiga

Int. J. Dev. Biol. (2008) 52: 969-977

https://doi.org/10.1387/ijdb.072541nt

Peter Holland, homeobox genes and the developmental basis of animal diversity

Sebastian M. Shimeld

Int. J. Dev. Biol. (2008) 52: 3-7

https://doi.org/10.1387/ijdb.072394ss

Developmental expression of the High Mobility Group B gene in the amphioxus, Branchiostoma belcheri tsingtauense

Xiangwei Huang, Lifeng Wang and Hongwei Zhang

Int. J. Dev. Biol. (2005) 49: 49-46

http://www.intjdevbiol.com/web/paper/041915xh

Cell morphology in amphioxus nerve cord may reflect the time course of cell differentiation T C Lacalli

Int. J. Dev. Biol. (2000) 44: 903-906

http://www.intjdevbiol.com/web/paper/11206331

Embryonic development of heads, skeletons and amphioxus: Edwin S. Goodrich revisited P W Holland

Int. J. Dev. Biol. (2000) 44: 29-34

http://www.intjdevbiol.com/web/paper/10761843

Amphioxus Hox genes: insights into evolution and development

$\mathrm{J}$ Garcia-Fernàndez and $\mathrm{P}$ W Holland

Int. J. Dev. Biol. (1996) 40: S71-S72

http://www.intjdevbiol.com/web/paper/9087701

5 yr ISI Impact Factor $(2013)=2.879$

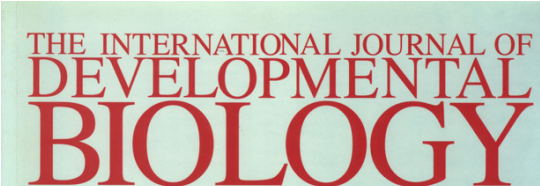

Volume 40 No. 4

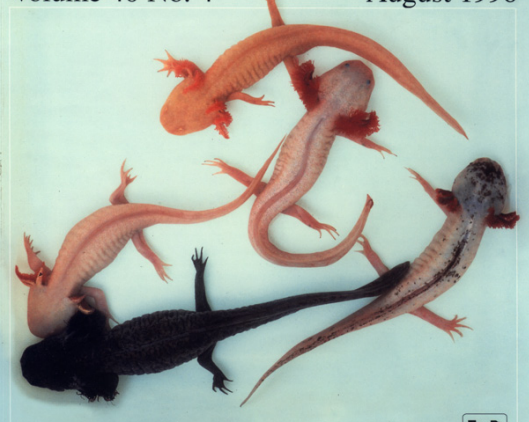

Developmental Biology of Urodeles $\xi_{0}^{*}$

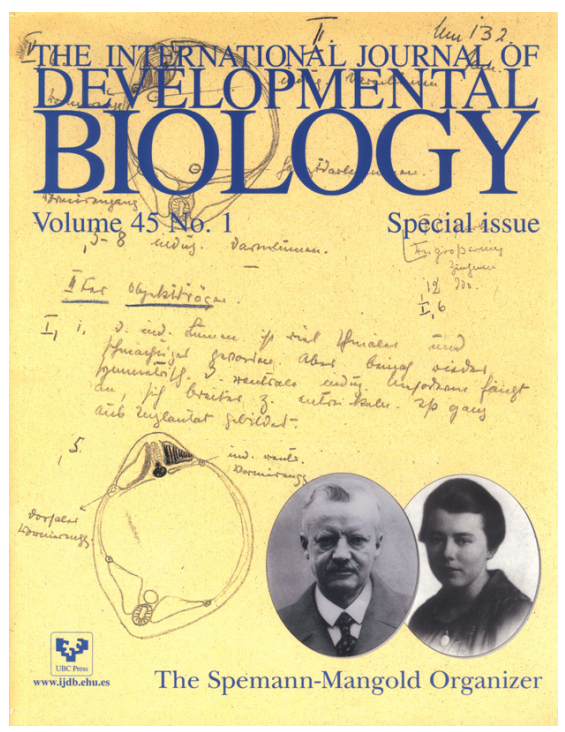

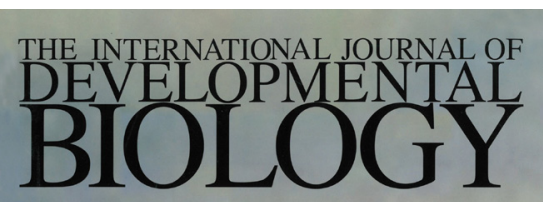

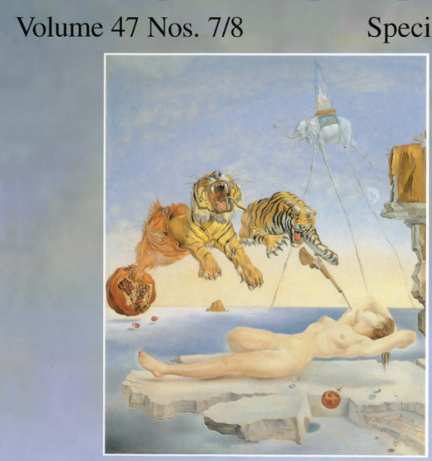

Evolution \& Development

5
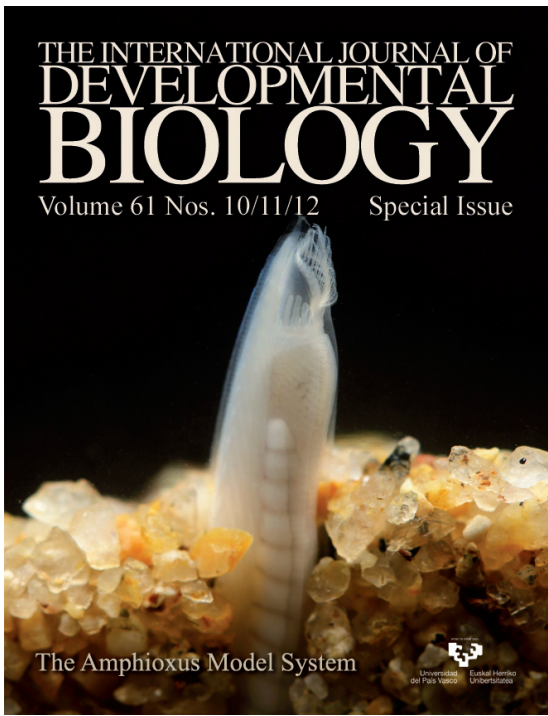